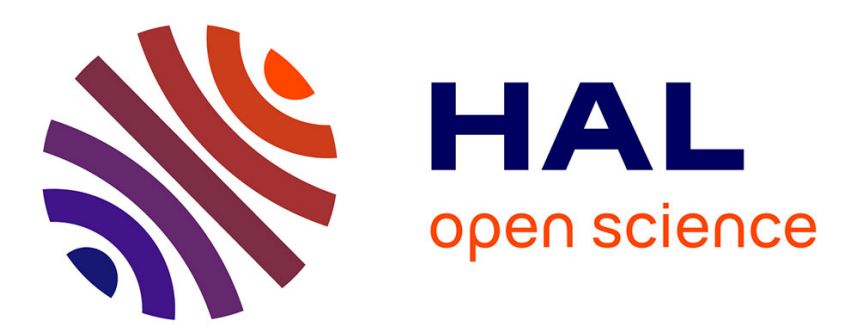

\title{
Observed temperature trends in the Indian Ocean over 1960-1999 and associated mechanisms
}

\author{
G. Alory, S. Wijffels, G. Meyers
}

\section{To cite this version:}

G. Alory, S. Wijffels, G. Meyers. Observed temperature trends in the Indian Ocean over 1960-1999 and associated mechanisms. Geophysical Research Letters, 2007, 34 (2), pp.L02606. 10.1029/2006GL028044 . hal-00406737

\section{HAL Id: hal-00406737 https://hal.science/hal-00406737}

Submitted on 6 Apr 2021

HAL is a multi-disciplinary open access archive for the deposit and dissemination of scientific research documents, whether they are published or not. The documents may come from teaching and research institutions in France or abroad, or from public or private research centers.
L'archive ouverte pluridisciplinaire HAL, est destinée au dépôt et à la diffusion de documents scientifiques de niveau recherche, publiés ou non, émanant des établissements d'enseignement et de recherche français ou étrangers, des laboratoires publics ou privés. 


\title{
Observed temperature trends in the Indian Ocean over 1960-1999 and associated mechanisms
}

\author{
Gaël Alory, ${ }^{1,2}$ Susan Wijffels, ${ }^{1}$ and Gary Meyers ${ }^{1,2}$ \\ Received 8 September 2006; revised 4 December 2006; accepted 12 December 2006; published 20 January 2007.
}

[1] The linear trends in oceanic temperature from 1960 to 1999 are estimated using the new Indian Ocean Thermal Archive (IOTA), a compilation of historical temperature profiles. Widespread surface warming is found, as in other data sets, and reproduced in IPCC climate model simulations for the 20th century. This warming is particularly large in the subtropics, and extends down to $800 \mathrm{~m}$ around $40-50^{\circ} \mathrm{S}$. Models suggest the deep-reaching subtropical warming is related to a $0.5^{\circ}$ southward shift of the subtropical gyre driven by a strengthening of the westerly winds, and associated with an upward trend in the Southern Annular Mode index. In the tropics, IOTA shows a subsurface cooling corresponding to a shoaling of the thermocline and increasing vertical stratification. Most models suggest this trend in the tropical Indian thermocline is likely associated with the observed weakening of the Pacific trade winds and transmitted to the Indian Ocean by the Indonesian throughflow. Citation: Alory, G., S. Wijffels, and G. Meyers (2007), Observed temperature trends in the Indian Ocean over 19601999 and associated mechanisms, Geophys. Res. Lett., 34, L02606, doi:10.1029/2006GL028044.

\section{Introduction}

[2] It is now well documented that global warming is underway, and at least partly due to anthropogenic greenhouse forcing [Levitus et al., 2001; Barnett et al., 2005]. The ocean plays a key role as it absorbs the vast majority of excess solar heating trapped by the greenhouse gases [Levitus et al., 2005]. Also as sea surface temperature (SST) strongly affects ocean-atmosphere coupling, we expect rising SST to affect natural modes of variability like ENSO (El Niño-Southern Oscillation) [Philip and van Oldenborgh, 2006]. In the Indian Ocean, interannual variability of SST is related both to the Indian Ocean Dipole [Saji et al., 1999] and ENSO [Reason et al., 2000]. Indian Ocean SST affects the monsoon regime [Krishnan et al., 2006] and Australian rainfall [Ashok et al., 2003]. Its increasing trend was found partly responsible for droughts in African Sahel [Giannini et al., 2003] and the midlatitude northern hemisphere [Hoerling and Kumar, 2003].

[3] The SST response to greenhouse warming is expected to be modulated by subsurface ocean dynamics. In the Indian Ocean, the long-term trends of subsurface temperature

\footnotetext{
${ }^{1}$ CSIRO Marine and Atmospheric Research, Hobart, Tasmania, Australia.

${ }^{2}$ Wealth from Oceans National Research Flagship, CSIRO, North Ryde, New South Wales, Australia.
}

Copyright 2007 by the American Geophysical Union. 0094-8276/07/2006GL028044 have been recently presented [Levitus et al., 2005], though, no interpretation for their spatial pattern has been given. A new compilation of historical temperature profiles, the Indian Ocean Thermal Archive (IOTA), is now available. It is used in this study to analyse long-term trends in subsurface temperature over the last 4 decades and relate them to SST trends. 20th century climate simulations from 10 IPCC AR4 (Intergovernmental Panel on Climate Change's Fourth Assessment Report) models are compared with these observations and used to investigate the oceanic mechanisms associated with the observed temperature changes.

\section{Data and Methods}

[4] IOTA is a compilation of historical temperature data above $1000 \mathrm{~m}$ in the Indian Ocean, which has been meticulously quality controlled using both statistical and manual expert methods (A. Gronell and S. E. Wijffels, Qualitycontrolling large historical temperature archives: a semiautomated approach, submitted to Journal of Atmospheric and Oceanic Technology, 2006). In addition, all WOCE (World Ocean Circulation Experiment) Indian Ocean data and Argo profiles available from 1999 onwards are used. The total number of profiles for $1960-2005$ is 430,000 with $85 \%$ reaching $100 \mathrm{~m}, 50 \%$ reaching $400 \mathrm{~m}$ and $20 \%$ reaching $800 \mathrm{~m}$. A mean seasonal climatology is formed using a "loess" mapping method similar to that of Ridgway et al. [2002], which deals well with varying data densities, a feature of this sparsely sampled ocean. To prevent the climatology from being biased regionally to years when data were many, a quadratic time change over 50 years was also included in the parametric model used in the "loess" filter. A robust fitting method was used to prevent any remaining outliers biasing the fits. The seasonal climatology will be described elsewhere. Here we examine the time tendency as represented by the linear trend. The fit is from 1960 to 1999 due to the very low data density before this period.

[5] To compare the IOTA surface data with much more comprehensive data sets, 2 gridded SST products are used. The Extended Reconstructed SST (ERSST) [Smith and Reynolds, 2004] and Hadley Ice SST (HADISST) [Rayner et al., 2003] are monthly reconstructions of SST based on combined satellite and in situ observations. Their spatial resolution is $2^{\circ}$ and $1^{\circ}$, respectively. The reconstructions use Empirical Orthogonal Functions from the satellite era to fill data gaps in the pre-satellite era.

[6] Monthly surface wind stress from the NCEP [Kistler et al., 2001] and ERA40 [Uppala et al., 2005] atmospheric reanalysis are also used. Their spatial resolution is respectively $2^{\circ}$ and $2.5^{\circ}$. 
Table 1. Models Used in the Present Study and Their Main Characteristics ${ }^{\mathrm{a}}$

\begin{tabular}{|c|c|c|c|c|c|c|}
\hline \multirow[b]{2}{*}{ Model/Data } & \multicolumn{2}{|c|}{ Resolution } & \multirow[b]{2}{*}{$\mathrm{O}_{3}$} & \multirow[b]{2}{*}{ Reference } & \multirow[b]{2}{*}{$\mathrm{T} \%$} & \multirow[b]{2}{*}{$\mathrm{ST} \%$} \\
\hline & Atmosphere & Ocean & & & & \\
\hline CSIRO-MK3 & $1.9 \times 1.9 \times 18$ & $1.9 \times 0.9 \times 31$ & $\mathrm{Y}$ & Gordon et al. [2002] & $46(-)$ & $100(+)$ \\
\hline MIROC3.2.HI & $1.12 \times 1.12 \times 56$ & $1.12 \times 0.56 \times 48$ & $\mathrm{Y}$ & Hasumi and Emori [2004] & $69(+)$ & $100(+)$ \\
\hline FGOALS1.0.G & $2.8 \times 2.8 \times 26$ & $1 \times 1 \times 33$ & $\mathrm{~N}$ & Yu et al. [2004] & $99(+)$ & $100(+)$ \\
\hline CGCM3.1-T47 & $3.75 \times 3.75 \times 31$ & $1.9 \times 1.9 \times 29$ & $\mathrm{~N}$ & Flato et al. [2000] & $100(+)$ & $100(+)$ \\
\hline CGCM3.1-T63 & $2.8 \times 2.8 \times 31$ & $1.4 \times 0.93 \times 29$ & $\mathrm{~N}$ & Flato et al. [2000] & $100(+)$ & $100(+)$ \\
\hline UKMO-HADCM3 & $3.75 \times 2.5 \times 19$ & $1.25 \times 1.25 \times 20$ & $\mathrm{Y}$ & Gordon et al. [2000] & $98(+)$ & $99(+)$ \\
\hline MRI-CGCM2.3.2 & $2.8 \times 2.8 \times 30$ & $2.5 \times 0.5 \times 23$ & $\mathrm{~N}$ & Yukimoto and Noda [2002] & $90(+)$ & $100(+)$ \\
\hline GFDL-CM2.1 & $2.5 \times 2 \times 24$ & $1 \times 0.33 \times 50$ & $\mathrm{Y}$ & Delworth et al. [2006] & $100(-)$ & $61(+)$ \\
\hline GFDL-CM2.0 & $2.5 \times 2 \times 24$ & $1 \times 0.33 \times 50$ & $\mathrm{Y}$ & Delworth et al. [2006] & $89(-)$ & $82(-)$ \\
\hline MIROC3.2.ME & $2.8 \times 2.8 \times 20$ & $1.4 \times 0.56 \times 44$ & $\mathrm{Y}$ & Hasumi and Emori [2004] & $92(+)$ & $5(+)$ \\
\hline IOTA & & & & & $81-100(-)$ & $98-100(+)$ \\
\hline
\end{tabular}

${ }^{\mathrm{a}}$ The grid resolution is given at the equator $\left({ }^{\circ}\right.$ longitude $\times{ }^{\circ}$ latitude $\times$ number of vertical levels). $\mathrm{O}_{3}$ shows whether ozone depletion forcing is included $(\mathrm{Y})$ or not $(\mathrm{N})$. T and ST refer to the tropical and subtropical boxes, respectively, from which indices in Figure 3 are derived. T\% and ST\% show the sign and probability of the 1960-1999 linear trend in temperature in the 20th century runs being larger than natural variability, where the probability density function of the latter was found from a running 40-year trend computed from the model control runs which range from 100 to 500 years. Since the observational record is so short, $\mathrm{T} \%$ and ST\% for IOTA are a range based on the probability density function of the models with the highest and lowest natural variability among the 10 models.

[7] We selected 10 IPCC models for which surface and subsurface temperature, barotropic stream function and surface wind variables were available (Table 1). The outputs from the 20th century climate experiments driven by natural and anthropogenic greenhouse gases, aerosol and ozone forcing (the latter not included in all models, see Table 1) can be compared to observations on the 1960-1999 period. At each grid-point, a least-square fit is used to extract the linear trend. Since some models have a spurious numerical
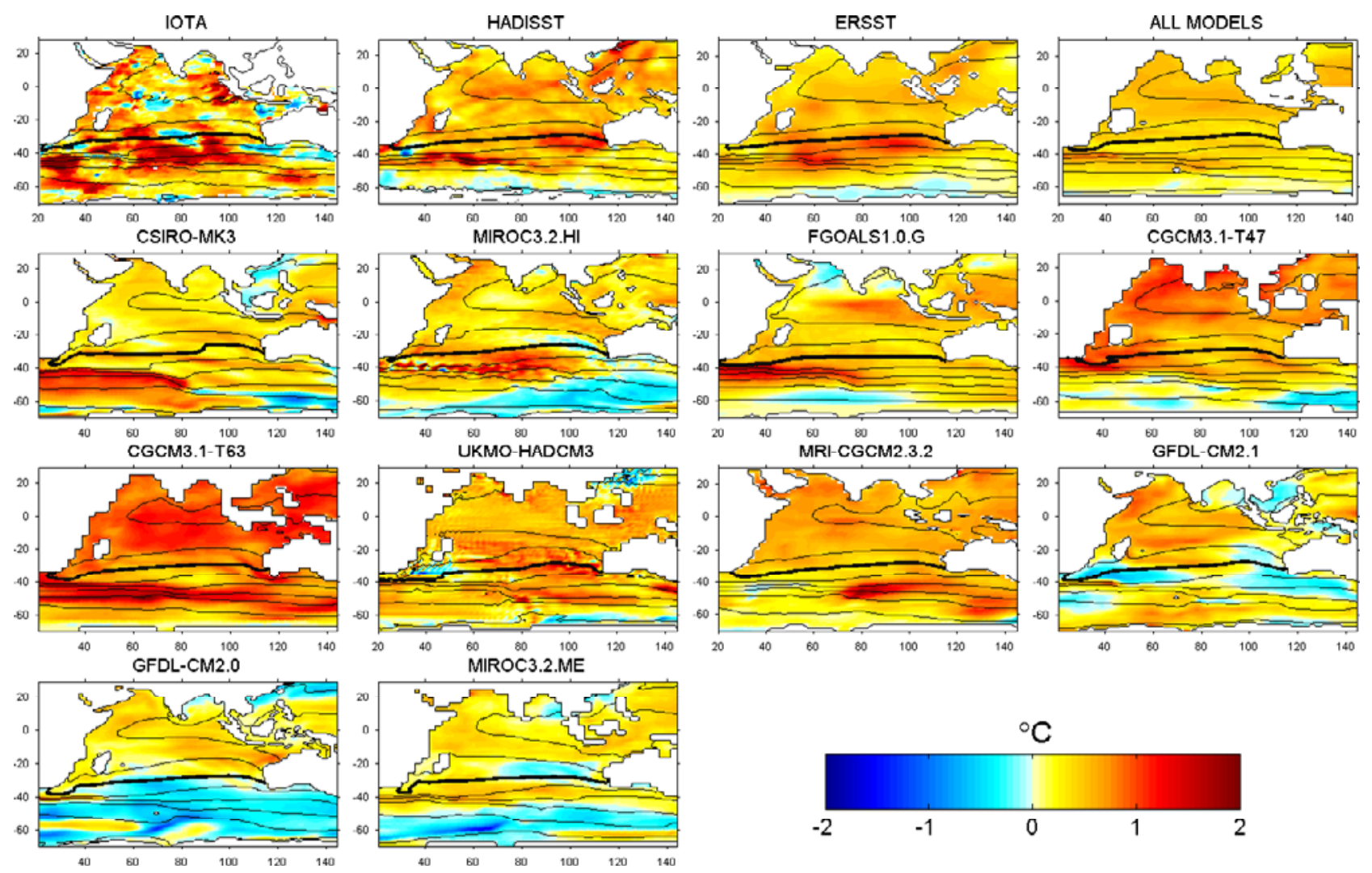

Figure 1. Linear trends in SST over 1960-1999 (colors, in ${ }^{\circ} \mathrm{C}$ ) and mean SST (contours every $4{ }^{\circ} \mathrm{C}, 20^{\circ} \mathrm{C}$ isotherm in bold).

drift, the trend of the control run is subtracted from the trend of the 20th century run, for the corresponding period.

\section{Results and Discussion}

[8] SST trends in the Indian Ocean, expressed as changes over 1960-1999, are compared for the different data sets and models (Figure 1). All data sets show warming nearly everywhere in the basin. The strongest warming is found in the western part of the subtropical gyre, around $40^{\circ} \mathrm{S}-50^{\circ} \mathrm{S}$,

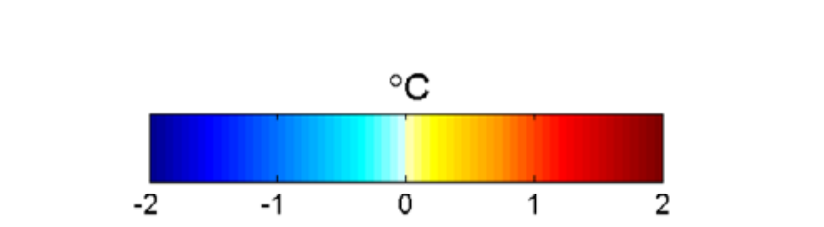



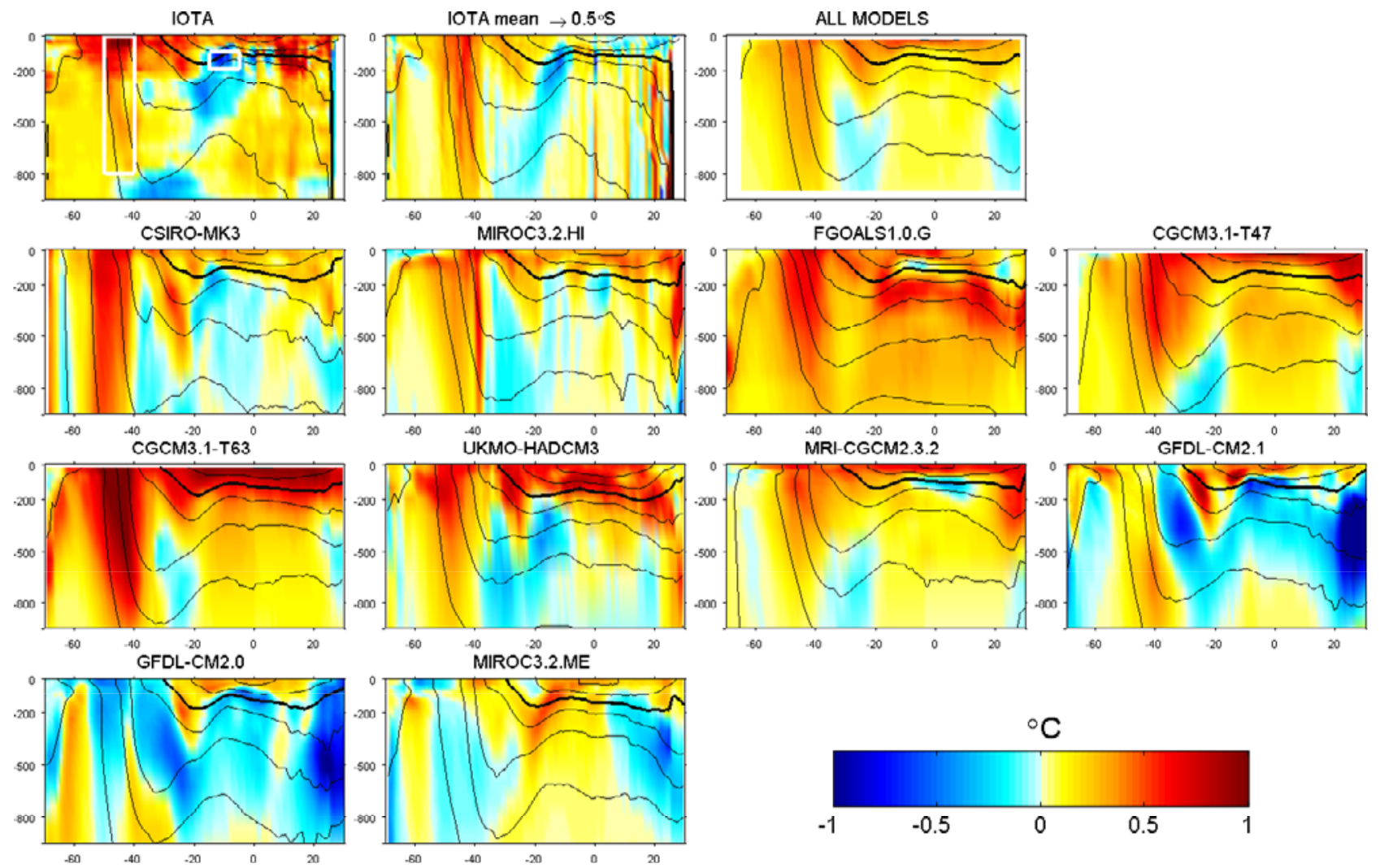

Figure 2. Zonally-averaged linear trends in subsurface temperature over 1960-1999 (colors, in ${ }^{\circ} \mathrm{C}$ ), and mean subsurface temperature (contours every $4^{\circ} \mathrm{C}, 20^{\circ} \mathrm{C}$ isotherm in bold). White boxes in the first panel are used to define trend indices shown in Figure 3. The second panel shows the trends expected from a $0.5^{\circ}$ southward shift of the observed mean temperature structure.

and corresponds to an increase of 1 to $2^{\circ} \mathrm{C}$ in SST over 40 years. In HADISST, this warming is concentrated in a narrow longitudinal band. In most of the data sets, this warming follows the mean isotherms to the south-east. Other important warming areas are found around $30^{\circ} \mathrm{S}$ off Western Australia and in the equatorial band, although these are weak in IOTA.

[9] SST trends simulated by models are quite different from one model to another. However, all models but two (GFDL-CM2.0 and MIROC3.2.ME) show a net warming in the basin. A robust feature among the models is the maximum warming along $40^{\circ} \mathrm{S}-50^{\circ} \mathrm{S}$, in agreement with the data sets. It is found in the western half of the basin in 4 of the models (CSIRO-MK3, MIROC3.2.HI, FGOALS1.0.G, CGCM3.1-T47), but only in the east in 2 models (UKMO-HADCM3 and MRI-CGCM2.3.2) and along all longitudes in one (CGCM3.1-T63). The 3 other models also show a hint of warming along $40^{\circ} \mathrm{S}$, although weaker and less extensive than the observed.

[10] In the zonally-averaged IOTA observations (Figure 2 ), the strong warming observed at the surface around $40^{\circ} \mathrm{S}-50^{\circ} \mathrm{S}$ extends down to $800 \mathrm{~m}$, where the nearly vertical mean isotherms mark the succession of the subtropical and sub-Antarctic fronts [Tomczak and Godfrey, 1994]. Note that in these latitudes of the Indian Ocean between $700 \mathrm{~m}$ and $1100 \mathrm{~m}$, a comparable warming has been independently reported from deep float observations [Gille,
2002]. North of the subtropical gyre, around $25^{\circ} \mathrm{S}$, a secondary warming is observed which extends down to $250 \mathrm{~m}$, while a patch of cooling is found near $400 \mathrm{~m}$ depth near $20^{\circ} \mathrm{S}$. In the tropics from $5^{\circ} \mathrm{N}$ to $15^{\circ} \mathrm{S}$, the surface warming is trapped above the thermocline, roughly delimited by the $20^{\circ} \mathrm{C}$ isotherm, while below we find a subsurface cooling around depths of 100-200 m. This pattern corresponds to a shoaling of the thermocline and an increase of vertical stratification at the base of the mixed layer. Strong warming north of $10^{\circ} \mathrm{S}$ down to $250 \mathrm{~m}$ is associated with the increasing SST in the Arabian Sea and Bay of Bengal (Figure 1). The overall pattern of changes is quite similar to the independent analysis of Levitus et al. [2005].

[11] In agreement with the data, all models with a strong SST increase around $45^{\circ} \mathrm{S}$ show deep warming below (Figure 2). Comparison of the western and eastern half of the basin (not shown) confirms that the subsurface warming follows the zonal location of the SST warming, and the location of the mean temperature fronts. The strong link between the surface and subsurface temperature trends can only be partly explained by the deep winter mixed layer (around $500 \mathrm{~m}$ ) found in these latitudes [de Boyer Montégut et al., 2004]. The observed warming around $25^{\circ} \mathrm{S}$ at $200 \mathrm{~m}$ depth is also found in most of the models. The 3 models with weak SST warming in the subtropics have only weak or no warming at depth. The GFDL models have a very 

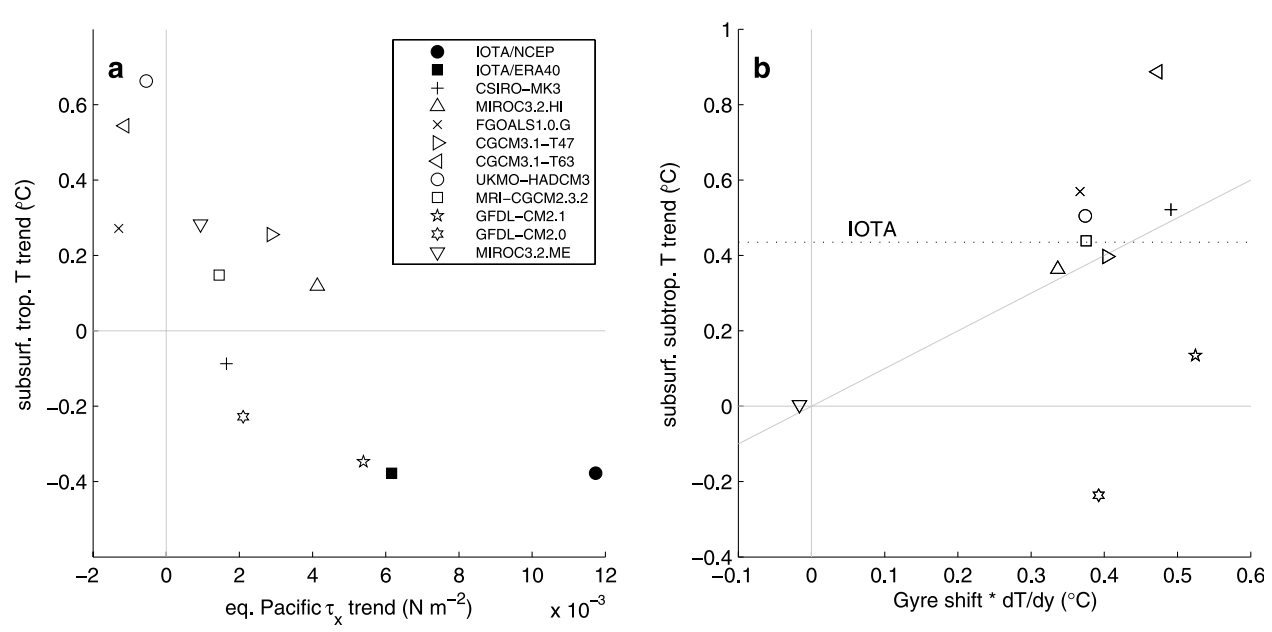

Figure 3. Scatter plots showing (a) the relation between the respective trends in the equatorial Pacific zonal wind stress $\left(5^{\circ} \mathrm{S}-5^{\circ} \mathrm{N}, 130^{\circ} \mathrm{E}-80^{\circ} \mathrm{W}\right.$, in $\mathrm{N} \mathrm{m}^{-2}$, positive when eastward) and in the tropical Indian subsurface temperature $\left(15^{\circ} \mathrm{S}-5^{\circ} \mathrm{S}\right.$, $100-200 \mathrm{~m}$, in ${ }^{\circ} \mathrm{C}$ ) and (b) the relation between the respective trends in the shift of the subtropical gyre, modulated by the mean meridional temperature gradient at $45^{\circ} \mathrm{S}$, and the subtropical temperature $\left(50^{\circ} \mathrm{S}-40^{\circ} \mathrm{S}, 0-800 \mathrm{~m}\right.$, in $\left.{ }^{\circ} \mathrm{C}\right)$. The shift of the gyre is defined as the latitude lag which maximizes the correlation between the 1960s and 1990s decadal means of the meridional profile $\left(50^{\circ} \mathrm{S}-20^{\circ} \mathrm{S}\right)$ of the barotropic stream function. The horizontal dashed line shows the amplitude of the observed subtropical warming.

distinct subtropical trend structure, with cooling in the center of the gyre.

[12] The observed subsurface cooling in the tropics is located in the latitude range that corresponds to the Indonesian Throughflow (ITF) which connects the Indian and Pacific oceans. At interannual timescales, thermocline depth anomalies associated with ENSO in the Pacific can be transmitted through the Indonesian region to the Indian Ocean where they propagate as Rossby waves [Wijffels and Meyers, 2004; Cai et al., 2005a]. By the same process, the shoaling of the western Pacific thermocline associated with a weakening trend in the equatorial Pacific trade winds observed over the last century [Vecchi et al., 2006] may be transmitted to the Indian Ocean.

[13] We test the validity of this oceanic teleconnection by comparing the trend in the equatorial Pacific winds with the trend in subsurface temperature in the tropical Indian Ocean in models and observations (Figure 3a). The atmospheric reanalysis products indeed show a weakening of the Pacific trade winds which may explain the subsurface cooling found in IOTA. The NCEP trend is twice that in ERA40, and is likely artificially strong as found by Alory et al. [2005]. The models have quite varying behaviours. Out of 10 models, 7 show a weakening of the Pacific winds and among them, 3 show a subsurface cooling. The 4 others show a subsurface warming though weaker than that at the surface (Figure 2). It may be that the adiabatic cooling due to the shoaling thermocline is competing with a surface diabatic warming in these models. Also, the box selected to quantify the subsurface temperature trend (see Figure 2), based on the latitude range of the ITF exit, does not capture some simulated cooling responses like that in MRICGCM2.3.2. However, the spatial extent of the cooling matches the unrealistically wide ITF in this model (Figure 1), suggesting a Pacific origin. Models with strengthening Pacific winds have the strongest subsurface warming in the tropics, and while the models show a large range of subsurface Indian temperature and Pacific wind trends, the good correlation $(r=-0.78$; significance $>99 \%)$ between the two responses over the ensemble of models and observation pairs suggests the proposed ocean teleconnection is at work.

[14] The deep reaching subtropical warming at $40^{\circ} \mathrm{S}-$ $50^{\circ} \mathrm{S}$ is the most robust feature in our trend analysis. The deep structure suggests this warming is related to changes in the barotropic circulation, the main component of oceanic circulation in these latitudes [Gill and Niiler, 1973]. As a lack of historical velocity observations means we cannot directly observe such a change, the coupled models which reproduce the observed warming can be used to identify the origins of this warming. Barotropic stream functions in all models show a well-defined subtropical gyre and significant long-term trends in the subtropics (not shown). In most models, these trends correspond to a southward shift of the gyre but with no significant change in its strength. By geostrophy, a southward shift of the subtropical gyre circulation would also imply a southward shift of the gyre's thermal structure.

[15] We thus compare the shift of the gyre, modulated by the meridional temperature gradient, to the subsurface trend in the subtropics (Figure 3b). For 6 of the models, (CSIROMK3, MIROC3.2.HI, FGOALS1.0.G, CGCM3.1-T47, UKMO-HADCM3, MRI-CGCM2.3.2), the southward shift of the gyre can quantitatively explain the simulated subtropical warming, which is quite similar to IOTA observations. In CGCM3.1-T63, the simulated warming is stronger than expected from the gyre shift. MIROC3.2.ME has no significant shift in the subtropical gyre and is coincidentally the only model with no hint of deep warming around $40^{\circ} \mathrm{S}-$ $50^{\circ} \mathrm{S}$. As noted previously, the GFDL models show an unusual trend structure in the subtropics, and while they simulate a southward shift of the barotropic gyre, it does not 
generate the expected temperature trend. Excluding these 2 models, the good correlation for the remaining models $(r=$ 0.84 ; significance $>99 \%$ ) in this parameter space suggests that the southward shift of the subtropical gyre, by about $0.5^{\circ}$ on average in the models, can account for the observed deep-reaching subtropical warming around $40^{\circ} \mathrm{S}-50^{\circ} \mathrm{S}$.

[16] The temperature change due to a southward shift of the gyre circulation was found by differencing the mean IOTA field from itself shifted by $0.5^{\circ}$ southward (second panel in Figure 2). This simple shift reproduces much of the observed temperature change in the subtropics over 19601999: strong warming from the surface to $800 \mathrm{~m}$ at $40^{\circ} \mathrm{S}-$ $50^{\circ} \mathrm{S}$, warming at $25^{\circ} \mathrm{S}$ to $200 \mathrm{~m}$ and cooling at $15^{\circ} \mathrm{S}$ around $400 \mathrm{~m}$. Thus, the trend pattern is directly related to the mean meridional gradient of temperature in these latitudes.

[17] To examine whether the tropical and subtropical trends in the 20th century runs could be due to natural internal variability, we compared their size with the multidecadal variability in the models' long control simulations (Table 1). In the subtropics, the warming trend is due to external forcing rather than internal variability at a $99 \%$ probability in 7 out of 10 models, and also in the observations (assuming the models' estimate of natural variability is correct). In the subsurface tropics, the trend is also due to forcing at a $90 \%$ probability for the observations and in 8 out of 10 models. Interestingly, the fact that a significantly forced warming or cooling (as observed) can be found suggests that there might be competing diabatic and adiabatic processes at work that reach a model-dependent balance.

\section{Summary and Conclusion}

[18] Observations show a widespread SST increase across the Indian Ocean over the last 4 decades, most pronounced near $40^{\circ} \mathrm{S}-50^{\circ} \mathrm{S}$ where it extends to around $800 \mathrm{~m}$ depth. Most of the 10 IPCC models used in this study are able to capture this trend and we show that it can be largely understood as a $0.5^{\circ}$ southward shift of the subtropical gyre.

[19] The trends observed in the subtropical Indian Ocean are in fact relatively similar to the trends observed in the South Pacific and South Atlantic oceans [Levitus et al., 2005], which suggests that similar mechanisms operate in these basins. Changes in the South Pacific subtropical gyre have indeed been observed over a recent 12 year period [Roemmich et al., 2006], but correspond to an increase in the gyre transport, which we did not find in the Indian Ocean.

[20] Subtropical gyres are driven by the wind curl due to the transition from the tropical trade winds to the high latitude westerlies, according to the Sverdrup theory. A southward shift and an increase in the southern hemisphere westerlies has been observed in the last decades, and related to the upward trend in the index of the Southern Annular Mode (SAM), the dominant mode of atmospheric variability in the Southern Hemisphere [Marshall, 2003; Thompson and Solomon, 2002]. Climate models show that such changes in the westerlies are expected to intensify in a global warming scenario, and to generate a poleward extension and spin up of the subtropical gyres [Saenko et al., 2005; Cai et al., 2005b]. Our results show that such changes in the ocean circulation are already at work and responsible for the observed deep warming.

[21] A recent multi-model study suggests ozone depletion and greenhouse forcing would contribute about equal parts to the already observed trend in the SAM [Cai and Cowan, 2006]. However, in response to the SAM trend, models with ozone forcing do not systematically show a larger subtropical warming than the others (see Table 1 and Figure 2). The subtropical warming amplitude is probably more affected by inter-model differences than by differences in the forcing.

[22] In the tropics, the observed shallow warming contrasts with a cooling of the main thermocline between $15^{\circ} \mathrm{S}$ and $5^{\circ} \mathrm{N}$. In models and observations, we find a link between the strength of the Pacific trade winds and Indian Ocean subsurface tropical temperature changes. On interannual timescales baroclinic waves in the Indonesian region transmit western Pacific thermocline variability into the Indian Ocean [Wijffels and Meyers, 2004; Cai et al., 2005a], and we suspect this oceanic teleconnection operates on the 40 year timescale as well.

[23] The modelled 20th century temperature changes were generally larger than those expected from internal dynamics and hence must be forced. However, the available AR4 runs do not allow us to identify which radiative forcing mechanism -aerosols (anthropogenic or natural), solar, greenhouse gases, ozone- are responsible for the changes.

[24] Acknowledgments. We acknowledge the modeling groups for providing their data and the PCMDI for archiving and making them available. NCEP reanalysis data were provided by the NOAA-ESRL PSD Climate Diagnostics Center Branch, Boulder Colorado from their Web site (http://www.cdc.noaa.gov/). ERA40 reanalysis data were retrieved from the ECMWF Data Server (http://www.ecmwf.int/). Wenju Cai and Ken Ridgway provided interesting comments which improved the paper. This work is partly funded by the South East Australian Climate Initiative. Comments from three anonymous reviewers greatly improved the paper.

\section{References}

Alory, G., S. Cravatte, T. Izumo, and K. B. Rodgers (2005), Validation of a decadal OGCM simulation for the tropical Pacific, Ocean Modell., 10 272-282, doi:10.1016/j.ocemod.2004.08.003.

Ashok, K., Z. Guan, and T. Yamagata (2003), Influence of the Indian Ocean Dipole on the Australian winter rainfall, Geophys. Res. Lett., 30(15), 1821, doi:10.1029/2003GL017926.

Barnett, T. P., D. W. Pierce, K. M. AchutaRao, P. J. Glecker, B. D. Santer, J. M. Gregory, and W. M. Washington (2005), Penetration of humaninduced warming into the world's oceans, Science, 309, 284-287.

Cai, W., and T. Cowan (2006), Trends in Southern Hemisphere circulation in IPCC AR4 models over 1950-1999: Ozone-depletion vs. greenhouse forcing, J. Clim, in press.

Cai, W., G. Meyers, and G. Shi (2005a), Transmission of ENSO signal to the Indian Ocean, Geophys. Res. Lett., 32, L05616, doi:10.1029/ 2004GL021736.

Cai, W., G. Shi, T. Cowan, D. Bi, and J. Ribbe (2005b), The response of the Southern Annular Mode, the East Australian Current, and the southern mid-latitude ocean circulation to global warming, Geophys. Res. Lett., 32, L23706, doi:10.1029/2005GL024701.

de Boyer Montégut, C., G. Madec, A. S. Fischer, A. Lazar, and D. Iudicone (2004), Mixed layer depth over the global ocean: An examination of profile data and a profile-base climatology, J. Geophys. Res., 109, C12003, doi:10.1029/2004JC002378.

Delworth, T. L., et al. (2006), GFDL's CM2 global coupled climate models. Part I: Formulation and simulation characteristics, J. Clim., 19, 643-674, doi:10.1175/JCLI3629.1.

Flato, G. M., G. J. Boer, W. G. Lee, N. A. McFarlane, D. Ramsden, M. C. Reader, and A. J. Weaver (2000), The Canadian Centre for Climate Modeling and Analysis global coupled model and its climate, Clim. Dyn., 16, 451-467.

Giannini, A., R. Saravanan, and P. Chang (2003), Oceanic forcing of Sahel rainfall on interannual to interdecadal time scales, Science, 302, $1027-$ 1030 
Gill, A., and P. Niiler (1973), The theory of the seasonal variability in the ocean, Deep Sea Res., 20, 141-177.

Gille, S. T. (2002), Warming of the Southern Ocean since the 1950s, Science, 295, 1275-1277.

Gordon, C., C. Cooper, C. Senior, H. Banks, J. Gregory, T. Johns, J. Mitchell, and R. Wood (2000), The simulation of SST, sea ice extents and ocean heat transports in the Hadley Centre coupled model without flux adjustments, Clim. Dyn., 16, 147-168.

Gordon, H. B., et al. (2002), The CSIRO Mk3 climate system model, Tech. Rep. 60, CSIRO Mar. and Atmos. Res., Aspendale, Victoria, Australia.

Hasumi, M., and S. Emori (2004), K-1 coupled GCM (MIROC) description, technical report, Cent. for Clim. Syst. Res., Univ. of Tokyo, Tokyo.

Hoerling, M., and A. Kumar (2003), The perfect ocean for drought, Science, 299, 691-694.

Kistler, R., et al. (2001), The NCEP-NCAR 50-year reanalysis, Bull. Am. Meteorol. Soc., 82(2), 247-267.

Krishnan, R., K. V. Ramesh, B. K. Samala, G. Meyers, J. M. Slingo, and M. J. Fennessy (2006), Indian Ocean-monsoon coupled interactions and impending monsoon droughts, Geophys. Res. Lett., 33, L08711, doi:10.1029/2006GL025811.

Levitus, S., J. I. Antonov, J. Wang, T. L. Delworth, K. W. Dixon, and A. J. Broccoli (2001), Anthropogenic warming of Earth's climate system, Science, 292, 267-270.

Levitus, S., J. Antonov, and T. Boyer (2005), Warming of the world ocean, 1955-2003, Geophys. Res. Lett., 32, L02604, doi:10.1029/ 2004GL021592.

Marshall, G. J. (2003), Trends in the southern annular mode from observations and reanalyses, J. Clim., 16, 4134-4143.

Philip, S., and G. J. van Oldenborgh (2006), Shifts in ENSO coupling processes under global warming, Geophys. Res. Lett., 33, L11704, doi:10.1029/2006GL026196.

Rayner, N. A., D. E. Parker, E. B. Horton, C. K. Holland, L. V. Alexander, D. P. Rowell, E. C. Kent, and A. Kaplan (2003), Global analyses of sea surface temperature, sea ice, and night marine air temperature since the late nineteenth century, J. Geophys. Res., 108(D14), 4407, doi:10.1029/ 2002JD002670.

Reason, C. J. C., R. J. Allan, J. A. Lindesay, and T. J. Ansell (2000), ENSO and climatic signals across the Indian Ocean Basin in the global context: Part I, Interannual composite patterns, Int. J. Clim., 20, 1285-1327.
Ridgway, K. R., J. R. Dunn, and J. L. Wilkin (2002), Ocean interpolation by four-dimensional weighted least squares - Application to the waters around Australasia, J. Atmos. Oceanic Technol., 19(9), 1357-1375.

Roemmich, D., J. Gilson, R. Davis, P. Sutton, S. Wijffels, and S. Riser (2006), Decadal spin-up of the South Pacific subtropical gyre, J. Phys. Oceanogr., in press

Saenko, O. A., J. C. Fyfe, and M. H. England (2005), On the response of the oceanic wind-driven circulation to atmospheric $\mathrm{CO}_{2}$ increase, Clim. Dyn., 25, 415-426, doi:10.1007/s00382-005-0032-5.

Saji, N. H., B. N. Goswani, P. N. Vinayachandran, and T. Yamagata (1999), A dipole mode in the tropical Indian Ocean, Nature, 401, 360-363, doi: $10.1038 / 43855$.

Smith, T. M., and R. W. Reynolds (2004), Improved extended reconstruction of SST (1854-1997), J. Clim., 17, 2466-2477.

Thompson, D. W. J., and S. Solomon (2002), Interpretation of recent Southern Hemisphere climate change, Science, 296, 895-899.

Tomczak, M., and J. S. Godfrey (1994), Regional Oceanography: An Introduction, 442 pp., Elsevier, New York.

Uppala, S. M., et al. (2005), The ERA-40 re-analysis, Q. J. R. Meteorol. Soc., 131, 2961-3012, doi:10.1256/qj.04.176.

Vecchi, G. A., B. J. Soden, A. T. Wittenberg, I. M. Held, A. Leetmaa, and M. J. Harrison (2006), Weakening of tropical Pacific atmospheric circulation due to anthropogenic forcing, Nature, 441, 73-76, doi:10.1038/ nature 04744 .

Wijffels, S., and G. Meyers (2004), An intersection of oceanic waveguides: Variability in the Indonesian throughflow region, J. Phys. Oceanogr., 34(5), $1232-1253$.

Yu, Y., X. Zhang, and Y. Guo (2004), Global coupled ocean-atmosphere general circulation models in LASGP/IAS, Adv. Atmos. Sci., 21, 444455.

Yukimoto, S., and A. Noda (2002), Improvements of the Meteorological Research Institute Global Ocean-Atmosphere Coupled GCM (MRICGCM2) and its climate sensitivity, Tech. Rep. 10, Natl. Inst. for Environ. Stud., Tsukuba, Japan.

G. Alory, G. Meyers, and S. Wijffels, CSIRO Marine and Atmospheric Research, GPO Box 1538, Hobart, TAS 7001, Australia. (gael.alory@ csiro.au) 